\title{
A Case of Osseous Choristoma of Thyroid Gland
}

\author{
Kyung Min Choi, Seung Woo Kim and Choon Dong Kim \\ Department of Otolaryngology-Head and Neck Surgery, Seoul Veterans Hospital, Seoul, Korea
}

\section{갑상선에 발생한 골성 분리종 1예}

최경민 · 김승우 · 김춘동

서울보훈병원 이비인후과

$\begin{array}{ll}\text { Received } & \text { September 29, } 2009 \\ \text { Revised } & \text { December 5, 2009 } \\ \text { Accepted } & \text { December 16, 2009 }\end{array}$

Address for correspondence

Seung Woo Kim, MD

Department of Otolaryngology-

Head and Neck Surgery,

Seoul Veterans Hospital,

Iljasan-gil, Gangdong-gu,

Seoul 134-791, Korea

Tel $+82-2-2225-1384$

Fax $+82-2-2225-1385$

E-mail rudaks10511@hanmail.net
Osseous choristoma rarely occurs, but when it does, the oral cavity of the head and neck lesion is the most common site. It appears as a mass of normal bony structure, consisting of mature osteocytes in an ectopic position. Appearing as a calcification of thyroid mass on radiologic examinations, it could be a benign lesion, chronic inflammation, or carcinoma; the final diagnosis can only be obtained by a pathologic confirmation. Histologically, the lesions show a well-circumscribed mass of vital bone. The treatment of choice is surgical excision. We report a case of osseous choristoma that occurred on the thyroid gland. To our knowledge, such has not been reported previously as a site of osseous choristoma.

Korean J Otorhinolaryngol-Head Neck Surg 2010;53:187-9

Key Words Thyroid gland · Osseous · Choristoma.
서 론

분리종이란 정상적인 세포들이 종양처럼 덩어리를 형성 하여 조직학적으로 신생물의 성격을 띄지는 않으나, 정상 적으로는 그 발생부위에서 발견될 수 없는 조직으로 이루 어져 있는 양성종양이다.

대부분의 분리종은 구강내 또는 구강주위 조직에서 발견 되며 이중 연골과 골조직으로 이루어진 분리종은 아주 드 물다. Kroll 등')에 의해서 구강내 연조직에 발생한 골성 분리종이 처음 소개되었고, 갑상선에서 생긴 경우는 국내에 서는 아직 보고된 예가 없으며, 외국에서는 1 예가 보고되어 있다. ${ }^{2)}$

최근 저자들은 갑상선 종괴를 주소로 내원한 남환에서 골성 분리종으로 진단된 증례를 문헌고찰과 함께 보고하는 바이다.

\section{증 례}

49세 남자 환자가 1 개월 전부터 발생한 우측 갑상선 종
괴로 본과에 의뢰되었다. 외상 후 스트레스성 장애로 정신 과에 입원 치료 중이던 환자로 갑상선 기능 검사상 Free $\mathrm{T} 4, \mathrm{~T} 3$ 수치가 약간 저하되었고, 갑상선 항체검사는 이상 없었다. 갑상선 초음파와 컴퓨터단층촬영을 시행한 결과상 우측 갑상선의 $0.8 \mathrm{~cm}$ 크기의 경계가 명확한 석회화 양상 의 결절 소견이 관찰되었다(Fig. 1). 유의한 경부증상은 호소하지 않았고, 과거력과 가족력, 음주 및 흡연력에서 특 이 소견은 없었다. 신체검사상 경부에 촉진되는 종물 소견 은 없었다. 결절 주변에서 시행한 초음파 유도 미세침세포 흡인검사상 결절성 증식증의 소견을 보였으며, 흡인을 시도 하였지만 불가능하여 중단하였다.

종괴 내에 석회화를 동반하고 있고, 환자가 수술을 원하 여, 갑상선 우엽 절제수술을 계획하였다. 주변조직과 잘 박 리되었고, 술 중 시행한 동결절편검사상에서는 석회화가 심 하여 진단이 불가능하다고 하여, 최종 조직검사 결과를 보 기로 하고 수술을 종료하였다.

병리조직검사상 우측 갑상선의 하극의 난원형의 석회화 결절이 관찰되었고, 성숙한 얇은 골 조직과 지방 조직이 관 찰되어 골성 분리종으로 진단되었다(Fig. 2). 술 후 합병 

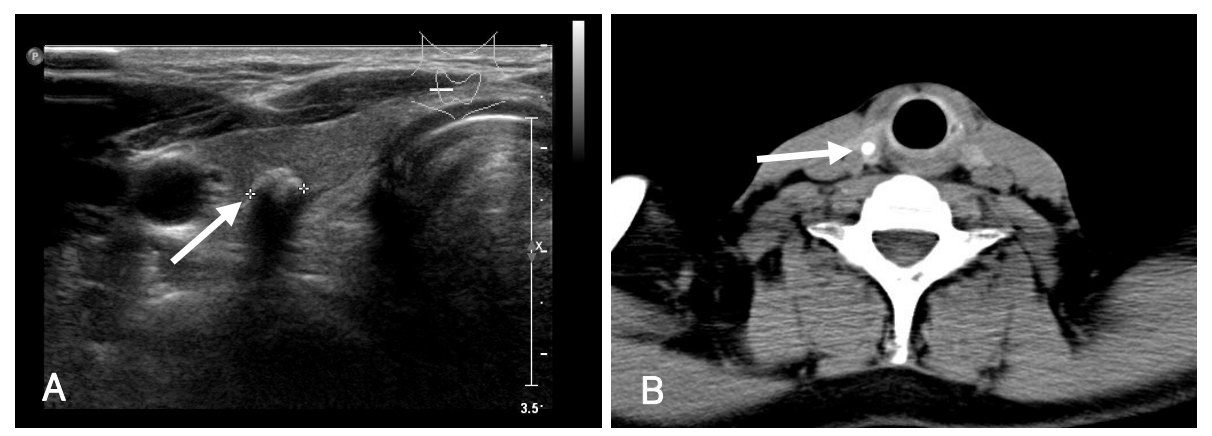

Fig. 1. Preoperative US (A) \& axial CT (B) scan shows $0.78 \mathrm{~cm}$ sized calcified nodule on lower pole of right thyroid gland (arrow).
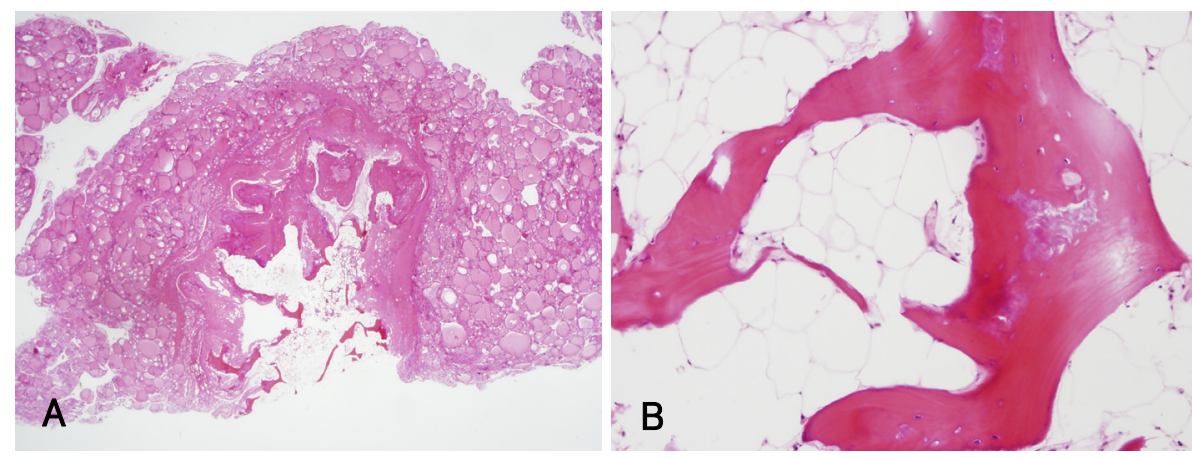

Fig. 2. Pathologic findings. Well-demarcated nodule was noted within the thyroid parenchyma ( $\mathrm{H} \& \mathrm{E}$ stain, $\times 12.5)(A)$. Composed of mature lamellar bone and adipose tissue $(\mathrm{H}$ \& E stain $\times 200)(B)$.

증 없이 6 일째 정신과로 다시 전과하였다. 현재 15 개월 동 안 재발 소견 없이 추적 관찰 중이다.

\section{고 찰}

골성 분리종은 피부골종 혹은 골종 등 ${ }^{3,4)}$ 으로 명명되어 왔 었고, Krolls 등'1)에 의해 처음으로 분리종으로 정의되었다. 분리종 ${ }^{4}$ 이란 원시세포의 조직이 원조직에서 멀리 떨어진 다른 부위에서 종양과 비슷한 성장을 하는 것을 의미한다.

두경부 영역에서는 혀에서 가장 빈번하게 발생하는 것으 로 알려져 있고, 협부점막, 협부전정, 악하부근 및 악하선, 대 구치, 저작근 등에서의 발생도 보고되어 있다. ${ }^{1,5-10)}$ 갑상선 에서 발생한 증례는 국내에서는 보고된 예가 없고, 국외에 서 1 예만이 보고되었다. ${ }^{2)}$

골성 분리종은 여성이 남성에 비해 약 3 배 정도 흔한 것 으로 보고되고, 초음파와 전산화단층촬영 소견상 조밀하고 잘 분화된 골종괴 소견을 보인다. 따라서 감별해야 할 질 환으로 섬유종, 유두종, 연골종, 골연골종, 설 갑상선 조직, 소타액선 종양, 악성 종양 등을 고려해야 한다. ${ }^{11)}$

초음파와 전산화단층촬영상에서 갑상선 종괴의 양성과 악성을 명확하게 구분하기는 쉽지 않고, 수술시 동결절편조 직검사상으로도 완전한 구분은 어렵다. 양성을 시사하는 소 견으로는 거친입자의 석회화와 비교적 명확한 경계, 명확한 테두리를 동반한 얇은 테 모양의 무에코성 낭종이 있을 경
우이고, 악성을 시사하는 소견으로는 경계가 불명확하고 비교적 두껍고, 특히 미세석회화 또는 테두리가 관찰될 경 우 악성을 의심할 수 있다.

발생 원인은 명확하게 밝혀져 있지는 않지만 몇 가지 가 설이 있다. 첫째, 배아 발생시 새궁의 중배엽에서 다능성 세포로부터 정상골조직이 분화되는 과정 중 일부가 고립되 어 형성한다는 가설이다. 둘째, 맹공에서 경부로 내려가지 않은 갑상선 조직이 사춘기에 골화가 이루어져 발생한다는 가설이다. 이를 뒷받침하는 사실로 설갑상선을 비롯한 이 소성 갑상선과 혀의 골종 및 골성 분리종이 모두 20대 여 성에서 흔하고, 갑상선 결절과 낭종에서 골화가 일어난다 는 점을 들 수 있다. 셋째, 기계적 외상, 만성 염증, 이물 등에 의해 화생 과정이 발생한 경우이다. ${ }^{12)}$

확진은 조직학적인 검사를 통해서만 가능하며, 경계가 분명하고 Haversian관이 잘 발달된 막성 골부로 구성되어 있으며 섬유성 결체조직에 의해 둘러싸여있다. 악성 종양, 골종, 골연골종 및 기타 석회화 병변에 대한 감별은 술중 동결절편검사로는 불가능하며, 최종 조직검사를 통해서만 가능하다.

치료는 외과적 절제를 통한 완전 절제를 시행하는 것이 며, 재발되는 경우는 거의 없는 것으로 알려져 있다. 따라 서 완전히 제거한 경우에는 이후 증상이 없으면 추적관찰 이 불필요하고, 불완전 제거를 한 경우 정기적인 추적관찰 이 필요할 것으로 사료된다. 
갑상선에서 골성 분리종은 이제까지 국내에는 보고된 예 가 없으며, 국외에도 1 예 밖에 보고된 바가 없다. 저자들 은 우연히 발견된 갑상선 종물을 주소로 내원한 49세 남 자 환자에서 외과적 절제술로 치험한 증례를 문헌 고찰과 함께 보고하는 바이다.

\section{REFERENCES}

1) Krolls SO, Jacoway JR, Alexander WN. Osseous choristomas (osteomas) of intraoral soft tissues. Oral Surg Oral Med Oral Pathol 1971; $32(4): 588-595$

2) Banerjee SN, Ananthakrishnan N, Veliath AJ, Ratnakar C. Osseous choristoma presenting as a cold solitary thyroid nodule. Postgrad Med J 1986;62 (733):1035-6.

3) Bejel H, Wilson $\mathrm{H}$, Stratigos $\mathrm{G}$, Zambito RF. Osteoma of the tongue: report of case. J Oral Surg 1968;26(10):662-4.

4) Dreizin DH, Masugi Y, Peimer R. Osteoma of the tongue. AMA Arch
Otolaryngol 1956;64(2):148-50.

5) Davis GB. Intraoral osseous choristoma: report of case. J Oral Surg 1980;38(2):144.

6) Tohill MJ, Green JG, Cohen DM. Intraoral osseous and cartilaginous choristoma: report of three cases and review of the literature. Oral Surg Oral Med Oral Pathol 1987;63 (4) :506-10.

7) Hodder SC, MacDonald DG. Osseous choristoma of buccal mucosa : report of a case. Br J Oral Maxillofac Surg 1988;26(1):78-80.

8) Long DE, Koutnick AW. Recurrent intraoral osseous choristoma. Report of a case. Oral Surg Oral Med Pathol 1991;72 (3):337-9.

9) Psimopoulou M, Antoniades K. Submental osseous choristoma: a case report. J Oral Maxillofac Surg 1998;56:666-7.

10) Dalkiz M, Hakan Yurdakul R, Pakdemirli E, Beydemir B. Recurrent osseous choristoma of the masster muscle: case report. J Oral Maxillofac Surg 2001;59 (7):836-9.

11) Bernard PJ, Shugar JM, Mitnick R, Som PM, Meyer R. Lingual osteoma. Arch Otolaryngol Head Neck Surg 1989;115 (8) :989-90.

12) Cho SH, Lee DW, Lee YS, Paik SS. A case of osteoma of the tongue. Korean J Otolaryngol-Head Neck Surg 2006;49 (3) :346-8. 